Editorial

\title{
Identity, Stigma, and Social Reaction
}

\author{
Daniel Kavish 1 \\ Criminal Justice, Department of Social Sciences, Southwestern Oklahoma State University, Weatherford, \\ OK 73096, USA; Daniel.kavish@swosu.edu
}

Received: 9 March 2020; Accepted: 11 March 2020; Published: 24 March 2020

check for updates

A great deal of theoretical and empirical work has examined the relationship between identity, social reaction, and stigma. Symbolic interaction, labeling, and identity perspectives identify how social reaction can perpetuate stigma and stereotypes. Furthermore, these perspectives describe the process of identity transformation and how subsequent behavior is influenced. Essentially, to understand social behavior, one must understand the relationships between social interaction, identity, and stigma.

Research on stigma is often rooted in Erving Goffman's foundational publication, "Stigma: Notes on the Management of Spoiled Identity" [1]. However, Goffman's contributions to understanding social interaction and stigma can be traced back even further by examining articles he wrote in the 1950s: "On Face-Work: An analysis of Ritual Elements in Social Interaction" [2], "Embarrassment and Social Organization" [3], "The Nature of Deference and Demeanor" [4], "Alienation from Interaction" [5]. These theoretical essay contributions were eventually reprinted as part of the book "Interaction Ritual: Essays on Face-to-Face Behavior" [6].

Erving Goffman, while influential in furthering discussions of social interaction, reaction, and stigma, was not the first scholar to address these topics. Other important contributions that provide the contemporary foundation for discussions of identity include, but are not limited to, Cooley's "Human Nature and the Social Order" [7], Mead's "The Psychology of Punitive Justice" and "Mind, Self, and Society" [8,9], Becker's "Outsiders" [10], Blumer's "Symbolic Interactionism Perspective and Method" [11], and Schur's "Labeling Deviant Behavior: Its Sociological Implications" [12]. Most of these contributions focused on how social interaction and stigma are interconnected with deviant or criminal behavior. However, theoretical discussions of stigma can help us better understand a variety of issues that are discussed by social science scholars beyond its relationship to deviance.

This Special Issue on Identity, Stigma, and Social Reaction seeks to provide a platform to highlight innovative articles that examine stigma from unique and creative perspectives. Two papers can be read in this Special Issue of Societies, these being two research articles that examine stigma in very different ways.

The article "Denying the Darkness: Exploring the Discourses of Neutralization of Bundy, Gacy, and Dahmer" [13], by Veronyka James, from Shenandoah University, explored how Ted Bundy, Jeffrey Dahmer, and John Wayne Gacy used techniques of neutralization to rationalize and justify their murders. James, based on the findings of a content analysis of case histories and interviews, argued that the aforementioned infamous serial killers relied on techniques of neutralization as a form of stigma management.

James' article, in addition to being supportive of prior research on identity and stigma management, contributed to criminological research by adding to the extent of literature that explores how individuals use techniques of neutralization as a form of stigma management. James asserted that techniques of neutralization serve as a means of controlling any narratives related to an individual's criminality and life. James' findings suggest that all individuals engaged in criminal behavior, not just persons that have committed crimes known to be more common (e.g., those that committed crimes such as theft or drug possession), use neutralizations as a form of stigma and identity management. 
The article entitled "Community Knowledge about Tuberculosis and Perception about Tuberculosis-Associated Stigma in Pakistan" [14], by Syed Mustafa Ali, Naveed Anjum, Muhammad Ishaq, Farah Naureen, Arif Noor, Aamna Rashid, all from Mercy Corps in Islamabad, Pakistan, Syed Muslim Abbas, from the Health Economics Unit at the University of Birmingham of the United Kingdom, and Kerri Viney, from the Department of Global Health at The Australian National University of Canberra, Australia assessed a local community's stigmatizing perceptions for, and knowledge of, tuberculosis (TB) in Pakistan. Their innovative study helped to bridge the gap between health research and sociology.

The authors examined a convenience sample of 183 individuals living in Pakistan in late 2017 and found a relationship between perceived stigma and a lack of knowledge about TB. Additionally, their research also found that biological sex, employment status, and an individual's education level were also significantly related to perceived stigma. While a clear majority of respondents knew that TB is curable and understood how it is transmitted, respondents also erroneously thought that TB could be "spread through contaminated food, sharing meals, sharing utensils, and by having sexual intercourse with a TB patient" [14]. Overall, their findings indicate that there is a need for improved education about TB among local communities in Pakistan.

Finally, these two contributions advance the value and importance of this Special Issue, by furthering sociological discussions of stigma and bridging the gap between different disciplines through interdisciplinary research. This Special Issue acknowledges the need to further develop research into identity, stigma, and social reaction.

As a guest editor, I would like to thank Dr. Gregor Wolbring, Editor-in-Chief of the Societies journal, for honoring me with this opportunity to edit this Special Issue on Identity, Stigma, and Social Reaction. I would also like to thank the reviewers for their exceptional and helpful work in evaluating manuscripts. Their evaluations greatly contributed to the overall quality of the published manuscripts. Likewise, I am thankful for the expertise of the Editorial Office of the Societies journal, and its Editorial Board, for their support in producing this Special Issue on Identity, Stigma, and Social Reaction. I would especially like to thank all the authors who submitted manuscripts for evaluation. Some of the manuscripts were not accepted because they did not fit the topic in question, others were rejected by reviewers for not conforming to expected methodological rigor. Regardless, I would like to express my appreciation to everyone that submitted a manuscript for consideration in this Special Issue on Identity, Stigma, and Social Reaction.

To conclude this Special Issue of Societies on Identity, Stigma, and Social Reaction, it should be noted that it sought to draw attention to studies that examine the dynamic relationship between stigma and social interaction. The role that stigma plays in the rationalizations serial killers provide for their actions was considered, and the relationship between knowledge of tuberculosis and stigma was discussed, thus uniquely contributing to the broadening and deepening of understandings of stigma and social interaction.

\section{References}

1. Goffman, E. Stigma: Notes on the Management of Spoiled Identity; Simon and Schuster: New York, NY, USA, 1963.

2. Goffman, E. On Face-Work: An Analysis of Ritual Elements in Social Interaction. Psychiatry 1955, 18, $213-231$. [CrossRef] [PubMed]

3. Goffman, E. Embarrassment and Social Organization. Am. J. Sociol. 1956, 62, 264-271. [CrossRef]

4. Goffman, E. The Nature of Deference and Demeanor. Am. Anthropol. 1956, 58, 473-502. [CrossRef]

5. Goffman, E. Alienation from Interaction. Hum. Relat. 1957, 10, 47-60. [CrossRef]

6. Goffman, E. Interaction Ritual: Essays in Face to Face Behavior; Transaction: Garden City, NY, USA, 1967.

7. Cooley, C.H. Human Nature and the Social Order; Charles Scribner's Sons: New York, NY, USA, 1902.

8. Mead, G.H. The Psychology of Punitive Justice. Am. J. Sociol. 1918, 23, 577-602. [CrossRef]

9. Mead, G.H. Mind, Self and Society; University of Chicago Press: Chicago, IL, USA, 1934.

10. Becker, H.S. Outsiders; Simon and Schuster: New York, NY, USA, 1963. 
11. Blumer, H. Symbolic Interactionism: Perspective and Method; University of California Press: Los Angeles, CA, USA, 1986.

12. Schur, E.M. Labeling Deviant Behavior: Its Sociological Implications; Harper \& Row: New York, NY, USA, 1971.

13. James, V. Denying the Darkness: Exploring the Discourses of Neutralization of Bundy, Gacy, and Dahmer. Societies 2019, 9, 46. [CrossRef]

14. Ali, S.M.; Anjum, N.; Ishaq, M.; Naureen, F.; Noor, A.; Rashid, A.; Abbas, S.M.; Viney, K. Community Knowledge about Tuberculosis and Perception about Tuberculosis-Associated Stigma in Pakistan. Societies 2019, 9, 9. [CrossRef]

(C) 2020 by the author. Licensee MDPI, Basel, Switzerland. This article is an open access article distributed under the terms and conditions of the Creative Commons Attribution (CC BY) license (http://creativecommons.org/licenses/by/4.0/). 